\title{
Paving New Roads Towards Biodiversity-Based Drug Development in Brazil: Lessons from the Past and Future Perspectives
}

\author{
Fernão Castro Braga ${ }^{1}$ (D)
}

Received: 4 August 2021 / Accepted: 25 August 2021 / Published online: 17 September 2021

(c) The Author(s) under exclusive licence to Sociedade Brasileira de Farmacognosia 2021

\begin{abstract}
Although Brazil gathers two fundamental features to occupy a leading position on the development of biodiversity-based medicines, the largest flora on earth and a broad tradition on the use of medicinal plants, the number of products derived from the national genetic heritage is so far modest, either as single drugs or as herbal medicines. This article highlights some aspects that may have contributed to the low rates of success and proposes new insights for innovation. We initially approach the use of medicinal plants in Brazil, molded by its ethnic diversity, and the development of the local pharmaceutical industry. A discussion of some governmental initiatives to support plant-based drug development is then presented. Employing the economic concept of "middle-income trap," we further propose that Brazil is stuck in a "middle-level science trap," since the increase in the number of scientific publications that launched the country to an intermediate publishing position has not been translated into drug development. Two new approaches to escape from this trap are presented, which may result in innovative drug development. The first is based on the exploitation of the antifragility properties of herbal products aiming to investigate non-canonical pharmacodynamics mechanisms of action, aligned with the concepts of system biology. The second is the manufacture of herbal products based on the circular economy principles, including the use of byproducts for the development of new therapeutical agents. The adoption of these strategies may result in innovative phytomedicines, with global competitiveness.
\end{abstract}

Keywords Circular economy $\cdot$ Biodiversity $\cdot$ Brazilian pharmaceutical industry $\cdot$ Innovative drug development $\cdot$ Medicinal plants $\cdot$ Public policies

\section{Introduction}

Brazil presents two fundamental features to foster the inhouse development of plant-based drugs: a rich biodiversity and a broad tradition on the use of medicinal plants. The country is considered to host the largest flora on earth, with 49,992 species of plants, algae, and fungi currently registered in different ecosystems (Flora do Brasil 2020). Nevertheless, the number of drugs developed from or based on constituents of the Brazilian biodiversity and traditional medicine is very

This article is part of a Special Issue to celebrate the 35th anniversary of the Brazilian Journal of Pharmacognosy

Fernão Castro Braga

fernaobraga@farmacia.ufmg.br

1 Departamento de Produtos Farmacêuticos, Faculdade de Farmácia, Universidade Federal de Minas Gerais, Av. Antônio Carlos 6627, Campus Pampulha, CEP 31.270-901, MG, Belo Horizonte, Brazil modest. The development of the antihypertensive drug captopril (1) and its analogues enalapril and lisinopril, based on the peptide phenylalanyl-prolyl-alanine (2), isolated from the venom of the Brazilian snake Bothrops jararaca is considered the country's most relevant contribution to pharmacotherapy (Newman 2017). The naphthoquinone lapachol (3), first isolated from Handroanthus impetiginosus (Mart. ex DC.) Mattos, Bignoniaceae (ipê-roxo), used for treating malaria in the late nineteenth century, was the template for the synthesis of the antimalarial drug atovaquone (4) (Looareesuwan et al. 1999). The alkaloid pilocarpine (5) can also be cited, obtained from leaves of Pilocarpus trees, Rutaceae (jaborandi), formerly used to treat glaucoma and currently employed to relieve xerostomia (Skirycz et al. 2016). Another example is tubocurarine chloride or $d$-tubocurarine (6), a constituent of the curare, a traditional preparation made with Chondrodendron tomentosum Ruiz \& Pav., Menispermaceae, introduced in anesthesiology in the 1940s due to its relaxing effect of skeletal musculature (Zhang et al. 2020). 
<smiles>C[C@H](CS)C(=O)N1CCCC1C(=O)O</smiles>

1<smiles>C[C@H](NC(=O)C(N)Cc1ccccc1)C(=O)N1CCCC1C(=O)[O-]</smiles>

2<smiles>CC(C)=CCC1=C(O)C(=O)c2ccccc2C1=O</smiles>

3<smiles>O=C1C(O)=C([C@H]2CC[C@H](c3ccc(Cl)cc3)CC2)C(=O)c2ccccc21</smiles>

4<smiles>CC[C@H]1C(=O)OC[C@@H]1Cc1cncn1C</smiles>

5<smiles>COc1cc2c(cc1Oc1cc(C[C@@H]3c4c(cc(OC)c(O)c4Oc4ccc(C[C@H]5CC[N+](C)(C)[C@@H]5C)cc4)CC[N+]3(C)C)ccc1O)CC[N+]2(C)C</smiles>

Brazil has a solid scientific basis for the investigation of medicinal plants, resulting from 70 years of governmental funding on graduate programs and the establishment of research infrastructures in public universities and institutes. Such long-term effort resulted in high numbers of scientific papers published in the field of medicinal plants in the last decades. Despite that, there seems to be a negative correlation between the number of published papers on Brazilian biodiversity and the number of innovative products derived from the Brazilian biomes introduced in the market (Calixto 2019). Besides the development of new drugs, the exploitation of the Brazilian biodiversity for medicinal purposes encompasses the validation of medicinal plants and their development as herbal medicines (HM). In this sense, another favorable condition for developing phytopharmaceutical products in Brazil is the solid framework established by the Brazilian Health Regulatory Agency (Anvisa) to regulate the approval of new HM, based on consistent pharmacological and toxicological pre-clinical and clinical data, in addition to strict quality requirements. As similarly observed for new drugs, the number of HM developed and registered to date is restricted in the country. Relevant products launched in the last years include Acheflan ${ }^{\circledR}$, an analgesic and antiinflammatory ointment obtained from the essential oil of Cordia curassavica (Jacq.) Roem. \& Schult. (syn. Cordia verbenacea DC.), Boraginaceae, Melagrião ${ }^{\circ}$, developed from the leaves of Mikania glomerata Spreng., Asteraceae, and used for the management of cough and asthma, along with Fitoscar ${ }^{\circledR}$, an ointment based on Stryphnodendron

adstringens (Mart.) Coville, Fabaceae, used in wound healing (Calixto 2019; Valli and Bolzani 2019). Despite the above-mentioned examples of success, the local herbal medicine market is very modest, totalizing ca. US\$ 261 million, which represents less than $5 \%$ of the global market of medicines in the country (Dutra et al. 2016). It should be also remembered that the small number of phytomedicines developed from native species is also reflected in the Brazilian public health (SUS) care system, since among the $12 \mathrm{HM}$ available in SUS, eight were developed from exotic plant species (Tabajara de Oliveira Martins et al., 2019). Besides, only $27 \%$ of the plants licensed as active pharmaceutical ingredients in HM in Brazil are native species (Carvalho et al. 2018). These findings are also reflected in the Brazilian Pharmacopoeia, whose all editions contained more exotic than native herbal drug species (Brandão et al. 2006; Anvisa 2010; 2019).

Before starting the analysis of the reasons why biodiversity-based drug development in Brazil presents low rates of success, we must highlight two fundamental aspects that might have impacted the process negatively and tend to aggravate it in forthcoming years. The first is the continuous process of destruction suffered by the native vegetation along the centuries, impacted by different economic activities. It caused, for instance, the ongoing preservation of only $12 \%$ of the original Atlantic Forest and $54 \%$ of the tropical savanna ecoregion ("cerrado"), two Brazilian biodiversity hotspots, which may have resulted in the loss of several bioactive species (Crouzeilles et al. 2017). The situation 
of the Amazonian Forest is equally alarming, since about $16 \%$ of the vegetation has already been lost and in 2020 the deforestation rate was $182 \%$ higher than the established target of the National Policy on Climate Change (Silva Junior et al. 2020). It is important to remember that the remaining native vegetation is still impacted by soy monoculture, sugar cane culture for ethanol production, cattle raising, and mining endeavors, among other economic activities, resulting in continuous increase of deforestation in these biomes (Crouzeilles et al. 2017).

The second fundamental aspect to be considered is the loss of traditional knowledge by indigenous populations. A survey carried out in Brazilian public markets indicated that only one-half of the commercialized medicinal plants were confirmed as the same vernacular name as in the Brazilian Pharmacopoeia, thus demonstrating a loss of knowledge of the original native species (Brandão et al. 2013). The access to Western medicines may result in the reduction in the use and loss of knowledge of medicinal plants in indigenous communities (Saethre 2007). Data collected from two Brazilian communities revealed that medicinal plants are preferred to manage simpler health problems, whereas Western medicine is mostly used for treating more complex conditions (Zank and Hanazaki 2017). The generational loss of traditional medicine knowledge is considered to be one of the greatest risks to using ethnopharmacology in the drug discovery process, along with the loss of the natural resources due to overexploitation and/or economic activities (Buenz et al. 2018). Therefore, the establishment of ethnobotanical databases to register plant species with traditional uses, their applications, and modes of uses constitutes a valid strategy for conservation of traditional knowledge, as recently reported for the Brazilian database Ewé (Souza and Hawkins 2020).

A verse of the National Anthem of Brazil, composed in 1831, translates well the dilemma faced nowadays by scientists and citizens related to the exploitation of the country's rich biodiversity: lying eternally on a splendid cradle ("deitado eternamente em berço esplêndido"). Only time will tell us if this verse is a prologue of a golden age still to come or the epitaph of untapped potential and wasted opportunities. To ignite the discussion, we herein examine some aspects that may have impaired the development of medicinal products from the Brazilian biodiversity and bring some ideas, concepts, and new paradigms that can be adopted to improve the process, or at least to be a source of inspiration. We will initially approach the historical basis on the use of medicinal plants in Brazil and the local pharmaceutical industry, followed by a discussion of some governmental initiatives to support plant-based drug development. Further, we will present new approaches that may improve the development of innovative products from the Brazilian genetic heritage, namely the exploitation of antifragility properties of herbal medicines and the manufacture of phytomedicines adopting the circular economy principles.

\section{Discussion}

\section{Medicinal Plants and the Pharmaceutical Industry}

Brazil is a melting pot of indigenous populations, European colonizers, and African slaves, resulting from the colonization process started by the Portuguese in the sixteenth century. This ethnic diversity molded the cultural identity of the nation and affected the use of medicinal plants and associated traditional knowledge. The ethnomedical practices of the native Brazilians encompass both naturalistic aspects and mystical rituals. Plants were employed to treat less severe diseases, whereas supernatural powers were evoked in the pursuit of healing in the case of more serious conditions (Gurgel 2011; Barbosa et al. 2016). African slaves introduced mystical elements in the set of traditional medicine practices, exerting its influence both on the indigenous population and European colonizers. Native Brazilians were considered to have a vast knowledge on plants: the Guarani people, for instance, was ascribed to have a deeper comprehension on plants than the Europeans of the sixteenth century (Mello 1980). Other authors, however, consider the Amerindian populations of Brazil as pre-agriculturalist societies since no written consensus around efficacious medicine existed. According to them, the biodiversity-based trial and error approach to treat diseases would have started only after the arrival of the European colonizer (Tabajara de Oliveira Martins et al., 2019).

The first investigations on the use of medicinal plants in Brazil are credited to the Jesuits, which performed empirical studies on medicinal plants motivated by the richness of the flora and by their contact with different indigenous ethnicities. As expected, there was a huge cultural shock between these groups regarding the curing practices and the religious attributed to the demons the healing arts exercised by the shamans-called by some Jesuits as "wicked sorcerers," "deceivers," and practitioners of the "lies of hell" (Barbosa et al. 2016). The erroneous association between medicinal plants and shamanism that persists in some segments of the Brazilian population probably derives from the aforementioned cultural differences, a fact that might limit recognizing phytotherapy as a valid scientific practice nowadays. The Jesuits were also responsible to develop formulas and remedies in the colony by fusing the Brazilian native flora and the European traditions, for example the Triaga Brasilica, a panacea composed by several native plants, which was also used internationally (Edler 2013). The outcomes of the Jesuits' studies were occasionally registered and constituted the first pharmacopoeic writings in the country (Teixeira 
and Edler 2012). However, the Historia Naturalis Brasiliae is considered the first scientific work on the Brazilian natural world and its traditional medical knowledge (Piso and Marggraf, 1648). In 1843, von Martius published the Systema Materiae Medicae Vegetabilis Brasiliensis, which describes 470 plant species, highlighting the abundance of plants used in the traditional medicine in the country (Mello 1980).

The use of plants for medicinal purposes experienced a continuous decline in Brazil throughout the twentieth century. This is reflected in the percentage of monographs of native herbal drugs included in the Brazilian Pharmacopoeia, which reduced from $27.5 \%$ in the first edition of 1929 to $15.6 \%$ and $17.4 \%$ in the 2nd and 3rd editions, published respectively in 1959 and 1977 . The percentage increased to $25 \%$ in the 4th edition of 1996 and remained nearly the same in the 5th and 6th editions of 2010 and 2019, respectively $26.9 \%$ and $22.5 \%$ (Anvisa 2010; 2019). Although the 1st and 6th editions of the Brazilian Pharmacopoeia present similar percentages of monographies of native species, the absolute number of plants varies substantially: it declined from 196 species in the first to 18 plants in the current edition (Anvisa 2019).

After the Second World War, there were tremendous advances in the field of organic synthesis that allowed the development of several synthetic drugs. The number of new drugs increased substantially until 1960, when the industry appeared to decline, at least in the USA, probably due to enactment of the Kefauver-Harris legislation, which required sponsors to demonstrate the safety and efficacy of new medicines, motivated by the public outrage due to the thalidomide disaster (Kinch et al. 2019). This period was characterized by an intense process of industrialization and urbanization in Brazil, and numerous international pharmaceutical industries began to operate globally and thereafter established in the country. This process, however, leads neither to the verticalization of the activities of the international companies settled in Brazil nor to the integration with local industries, since their actions were basically focused on the production and marketing (Centro de Gestão e Estudos Estratégicos 2017). Afterwards, the official medicine was almost exclusively based on synthetic drugs. This change of paradigm might explain the reduction in the number of monographies of native plants in the Brazilian Pharmacopoeia along the editions and the general loss of interest on medicinal plants by the local industries.

In the 1970s, the national pharmaceutical companies operated primarily through the representation of foreign brands, which allowed the development of commercial training. The absence of industrial property rights for pharmaceutical products and processes in this period enabled the skills of reverse engineering required to produce reference medicines. The Brazilian market has become the most important in sales in Latin America and the seventh in the world, although $75 \%$ of it was represented by multinational pharmaceutical companies (Centro de Gestão e Estudos Estratégicos 2017). In the following decade, there were government initiatives to improve technological skills of the sector, majorly based on technology transfer efforts. Although relevant, these initiatives did not strengthen the local industries, and the participation of multinational companies reached $85 \%$ of the market by the end of the decade (Oliveira 2005, Gadelha and Maldonado 2008). In the 1990s, trade liberalization and macroeconomic stabilization culminated in the expansion of imported pharmaceutical products. Important steps to regulate the pharmaceutical sector according to international standards were taken in this period. The National Medicines Policy was approved in accordance with the guidelines of the World Health Organization (WHO) (Bermudez et al. 2000) that subsequently allowed the establishment of Anvisa.

The law of generic drugs adopted in 1999 was responsible for the boom of the Brazilian pharmaceutical economy occurred in the following decades. The number of pharmaceutical companies quadruplicated from 2000 to 2006, whereas the presentations sold boosted 18 times in the period (Quental et al. 2008). In 2018, 34.7\% of pharmaceutical products recorded in Anvisa Drug Market Monitoring System (Sammed) are generic drugs and $35.2 \%$ are similar drugs. Together, they sold more than $67 \%$ of 12,383 pharmaceutical presentations and had a $35 \%$ share in the total revenues of the companies, which was $\mathrm{R} \$ 76.3$ billion in the year (Vieira and Santos 2020). This successful economic result might explain the lack of interest on research and development (R\&D) of biodiversity-based drugs by the inhouse companies. Although the generic drugs boom promoted the growth of national companies and stimulated partnerships between companies and institutions of science and technology, it did not bring high impact innovations, probably due to low investments on R\&D. Internal investments by the local pharmaceutical industries totalized $0.7 \%$ of their revenues in 2005 and $4.9 \%$ in 2014, while the 33 largest multinational pharmaceutical and biotechnology industries invested, in average, $15.9 \%$ of their revenues (Paranhos et al. 2019; Vieira and Santos 2020). To modernize and expand the productive capacity of national pharmaceutical companies and their alignment with regulatory aspects, the National Bank for Economic and Social Development (BNDES) launched a program to support the development of the pharmaceutical production chain (Profarma) in 2004, which was further expanded to the Health Industrial Complex (CIS) to stimulate the creation of technological capacities through systematic investment in innovation (Gomes et al. 2014).

The regulatory mark for the exploitation of the Brazilian biodiversity was established in 2015 by the Law no. 13123 that provides for access to genetic heritage, as well as the 
protection and access to associated traditional knowledge and on the benefit sharing for conservation and sustainable use of biodiversity. It is important to notice that this Law came only after 23 years of Rio Eco 92 when the Convention of Biological Diversity was approved and the free access to biological resources was abolished. Important unfolding of the Law 13,123 occurred with the creation of the National System of Genetic Heritage Management and Associated Traditional Knowledge, SisGen, an electronic system that works as an auxiliary instrument of the Genetic Heritage Management Board, CGen, in the management of genetic heritage and associated traditional knowledge. The establishment of this regulatory framework shall be translated into a scenario that is more conducive to the development of products from medicinal plants in Brazil, with the guarantees ensured to all actors involved. After a period of high market growth based on generic drugs, the companies need to base their strategies on products that provide competitive differential, looking at a fiercer scenario of competition. The establishment of the legal framework for developing biodiversity-based drugs and the new techniques available for drug discovery may encourage inhouse companies to seek radical innovations, taking on greater prominence in pharmaceutical R\&D (Pimentel et al. 2015).

\section{Public Policy Initiatives}

So far, the Brazilian state has played a minor role to improve the pharmaceutical sector, and the applied policies are considered insufficient and scarce. Some of these policies were formulated but never implemented, like the establishment of the state company Farmoquímica Brasileira S/A (Farmobrás) in the 1960s (Vieira and Santos 2020). Only two decades ago, the country adopted measures to promote the sector, with the Generic Drugs Act in 1999, and the institution of financing lines through the BNDES, from 2004. This situation contributed to maintain the dependency on imported synthetic products and driven the national pharmaceutical companies to prioritize activities focused on the internal market, a fact that may be also related to their low technological capacity (Françoso and Strachman 2013).

The governmental initiatives undertaken until now in Brazil to promote the exploitation of national biodiversity for medicinal purposes were mainly focused on the development of herbal products. This fact can be ascribed to the technological challenges faced for developing a single chemical entity into a drug, as well as the long time required for the process, in addition to the low rates of success and huge investments, now estimated to reach up to US\$ 2.8 billion (Wouters et al. 2020). Such conditions restrict the participation of national companies in the process and favored their focus on herbal products, considered to demand much lower investments for R\&D, like the US\$ 5 million reported for Acheflan ${ }^{\circledR}$ development (Calixto 2005).

One pioneer action assigned to develop herbal medicines from Brazilian medicinal plants was implemented by the extinct federal agency Central de Medicamentos (CEME) through the Medicinal Plants Research Program (PPPM), in the 1980s. Between 1983 and 1997, a total of 110 projects was funded by CEME within the program for studying 65 plant species by research groups of 24 institutions, totalizing nearly US\$ 8 million in investment (Sant'Ana and Assad 2004). By the time CEME was terminated in 1997, the research activities of eight plants were at final stages of preclinical studies and/or beginning of clinical assays, namely Maytenus ilicifolia Mart. ex Reissek, Celastraceae, Phyllanthus niruri L., Phyllanthaceae, Mikania glomerata Spreng., Asteraceae, Allium sativum L., Amaryllidaceae, Passiflora edulis Sims, Passifloraceae, Cuphea aperta Koehne, Lythraceae, Cymbopogon citratus (DC.) Stapf, Poaceae, and Cecropia glaziovii Snethl, Urticaceae. Although the goal of PPPM was to undertake R\&D activities of the native flora, two of the above-mentioned species, A. sativum and C. citratus, are exotic plants.

The research efforts conducted within PPPM did not result in the development of one single herbal product, but the initiative contributed with the pharmacological knowledge of selected plants and promoted the formation and consolidation of human resources and research groups in the fields of botany, agronomy, pre-clinical pharmacology, animal toxicology, and clinical pharmacology (Ministério da Saúde 2006). However, the major identified problems during PPPM implementation persist, like the dispersion of resources, lack of concrete results, absence of research coordination, and deficiencies in infrastructure and human resources (Sant'Ana and Assad 2004). The dispersion of funds is noticeable, since nearly US\$ 8 million were spent to finance 110 projects, a similar order of magnitude of the expenditures reported for developing one single productAcheflan ${ }^{\circledR}$ (Calixto 2005).

Fifty-five out of 74 plant species selected for PPPM were studied, of which 50 were submitted to pre-clinical pharmacology trials, 15 to clinical trials, and 30 were evaluated toxicologically. Of the 15 species submitted to clinical trials, nine confirmed the actions popularly attributed (Ministério da Saúde 2006). There was a marked prioritization on preclinic and clinic pharmacological projects- $64 \%$ of the total funded - and they were apparently developed without joint chemical investigations, including the identification of active markers and standardization of the plant drugs and phytopharmaceuticals. Moreover, difficulties related to the acquisition, botanical characterization, and quality control of medicinal plants, pointed out as limiting factors by the industrial sector, were not solved within the program (Sant'Ana and Assad 2004). The non-disclosure of the results obtained 
from PPPM is another fragility of the program. Until 1991, 28 species had studies conducted, of which only five had the results officially published by CEME (Ministério da Saúde 2006). These problems seem to continue until now, despite other governmental initiatives on the theme that followed PPPM.

The establishment of the National Policy on Medicinal Plants and Herbal Products in 2006 was a landmark in the area. The policy establishes guidelines and priority lines for different partners to act around common goals to ensure the safe access and rational use of medicinal plants and herbal products, in addition to the development of technologies and innovations, the strengthening of production chains and production arrangements, along with the sustainable use of biodiversity and the development of the Health Productive Complex (Ministério da Saúde 2009). Two years later, the National Policy on Integrative and Complementary Practices (PNPIC) was introduced at the Brazilian public health system (SUS). The policy aimed to incorporate and implement integrative and complementary practices (ICPs) in SUS, including medicinal plants and herbal medicines (Ministério da Saúde 2009). The National Program of Medicinal Plants and Herbal Products was launched in 2008 to operationalize the federal policy on medicinal plants of 2006. One of its goals is to implement phytotherapy in SUS following the requirements of safety, efficacy, and quality established by PNPIC (Ministério da Saúde 2009).

The above-mentioned policies and program were fundamental to expand the use of phytotherapy in SUS, being observed a remarkable growth in the number of programs throughout the country from 2006. However, this policy has not necessarily contributed to strengthen regional biodiversity and socio-diversity of the programs (Ribeiro 2019). The adherence to ICPs practices is still limited in Brazil: a recent survey indicates a prevalence of use of $4.1 \%$, while the most used types were medicinal plants and phytotherapy (2.5\%). Interestingly, the prevalence of ICPs use was higher in the North Region, among older people, women, participants with higher educational attainment, and with a higher number of chronic diseases (Boing et al. 2019). This finding indicates that social, regional, and economic features also influence the acceptance and use of herbal products in Brazil.

Another relevant initiative to be mentioned is the project "Plants for the Future," launched by the Ministry of the Environment (MMA) in 2005. This project aimed to gather scientific information of plants potentially useful for economic exploitation, occurring in distinct geographic regions of the country. For this purpose, an extensive survey of the scientific literature was carried out to recover information on pharmacological activities, chemical composition, agronomical aspects, botanical description, and traditional uses of selected plants, among other data. This initiative is important to disclose plants that shall be prioritized for investigation in future $R \& D$ projects to generate new pharmaceutical products. The lack of clinical studies was identified as a deficiency common to most of them, as well as the lack of an established production chain, capable of supplying the plant drug with quality and amount required for industrial use. Moreover, in some cases, it is necessary to identify the active marker of the species, to enable the quality control of plant drug, and to monitor the actions of technological transformation to obtain intermediate derivatives and final herbal products. A series of books with monographies of the priority plants defined so far is being released by MMA, available for download at the MMA website (https://www. mma.gov.br/publicacoes/biodiversidade/category/54-agrob iodiversidade.html).

\section{Insights for Reflection and Innovation}

Whatever a myth or reality, some researchers do believe that the economic development condition known as "middle-income trap" applies to Brazil nowadays, a situation in which a country that has attained a certain income level remains incapable to further reach higher per capita income growth. Such countries have experienced rapid growth from low-income to middle-income levels-propelled by reallocation of labor and capital from low-productivity sectors like traditional agriculture to export-driven to manufacturing-followed by lower growth, limited industrial diversification, and lack of high-quality and innovative products (Larson et al. 2016). We can borrow the economic concept of "middle-income trap" and apply it into the current scientific research scenario in Brazil, notably because science and technology development is crucial for promoting productivity advancement and, hence, further per capita income growth.

Between 2002 and 2014, the country experienced a sharp growth in the number of published scientific articles resulting from increases in research funding. In 1996, Brazil was ranked $21^{\text {st }}$ among all countries worldwide in the publication of citable documents (articles, reviews, and conference papers) across all areas of science in the SCImago database (http://www.scimagojr.com) (Rodrigues and Morel 2016). It was ranked in $13^{\text {th }}$ place in 2015 and at the $14^{\text {th }}$ position in the most recent SCImago analysis (2020). The growth in the last two decades was remarkable, but the effects of the economic crises from 2014 and rising currency exchange rates that affected funding for science are visible. Despite that, Brazil still occupies a middle position in the ranking but seems to be stuck at that place. According to the last SCImago analysis, the $\mathrm{H}$ index of Brazil (649) is much lower than closely ranked countries, either bellow $\left(e . g .15^{\text {th }}\right.$ position Netherlands, $\mathrm{H} 1333 ; 16^{\text {th }}$ position Switzerland, H 
1085) or above (e.g. $11^{\text {th }}$ position Spain, H $1010 ; 10^{\text {th }}$ position Australia, H 1115) its position. Although a simplistic analysis, the $\mathrm{H}$ index of Brazil reflects the low impact of the scientific production generated in the country. Besides, the remarkable increase in publications, previously mentioned, has not been translated into scientific development in Brazil, at least if we consider drug development. We can therefore conclude that Brazil is stuck in a "middle-level science trap."

\section{Exploring System Biology and Antifragility}

To escape from the trap and obtain success in the development of biodiversity-derived products is mandatory to adopt innovative approaches. Phenotypic screening is again at the forefront of drug discovery due to its ability to detect interactions with multiple targets to elicit the desired biological activity, in addition to detect unwanted side effects. Targetbased drug discovery, on the contrary, focusses on a single molecular target for compound development, which is not a representative model for the complex disease environment (Jörg and Madden 2021). This finding is aligned with the directives of system biology, defined as a holistic approach to decode the complexity of biological systems that starts from the understanding that the networks that form the whole of living organisms are more than the sum of their parts (https://isbscience.org/about/what-is-systems-biolo gy/). System biology constitutes a modern approach to the R\&D of herbal medicines in a non-reductionist way (Fig. 1). The bioactive constituents of a medicinal plant often work in a synergistic manner to elicit its therapeutic effect, and isolating the individual components may be counterproductive. Instead of looking for a specific molecule with a specific target, system biology focuses the complete equilibrium of a physiological system undergoing synchronized mechanisms on multiple molecular targets; in other words, it assumes a holistic vision of the pharmacological effects (Thomford et al. 2018).

Besides, the use of omics technologies like genomics, transcriptomics, proteomics, and metabolomics may offer a deeper understanding of the pharmacological effects, pathways, and mechanisms of action of herbal medicines. Their combination with system biology, along with automation and computational strategies, including artificial intelligence (Khan et al. 2021), can accelerate the development of innovative herbal medicines (Thomford et al. 2018). Moreover, new strategies for the identification of molecules in complex mixtures and their structure determination are available, resulting from the advances in analytical techniques, in addition to progress in chemometrics, data processing, and machine learning approaches (Goodacre 2019), with or without relations to bioassay screening data (Wolfender et al. 2019).
Plant extracts and complex herbal formulas are considered "complex systems" since they contain hundreds of compounds (Gong et al. 2012). They present a supramolecular architecture, with nonuniform distribution of their constituents over large length scales. Regions of higher and lower solute concentrations also coexist in solution, and predicting biological effects based solely on their chemical composition is not straightforward (Bizzarri et al. 2020). In addition to the classical pharmacodynamic mechanisms of action, plant-derived products also induce biological responses by physical and unconventional pharmacodynamics mechanisms, such as supramolecular chemistry, enhancement of absorption, changes on surface tension, and chelating effects on toxic ions, among others, and they should be integrated within network models currently in use (Bizzarri et al. 2020). This finding opens new venues for investigating the biological effects of herbal medicines through the concept of antifragility.

Antifragility is a property of systems that increases in capability in response to external perturbation like stressors, variability, volatility, randomness, or disorder (Taleb 2012). A simple demonstration of antifragility can be given by the stress suffered by the muscle fibers during lifting weights: the body adapts to lift heavier weights subsequently. To date, the concept has been mainly applied to computer science, economics, and management, with a few applications in medicine (Kaempf et al. 2017; Fiorini et al. 2015; Fatovich 2021). Taleb (2018) applied risk analysis to medical problems through the properties of nonlinear responses and described "antifragility" as a mathematical property for local convex response and "fragility" as its opposite, locally concave (Fig. 1). The author proposed a framework to integrate the consequences of nonlinearities in evidence-based medicine and medical risk management. Recently, a predictive method was developed to measure antifragility, and it was successfully applied to predict the robustness and evolvability of biological networks (Kim et al. 2020).

Antifragility was measured in seven different biological systems, and they all showed antifragile dynamics (Pineda et al. 2019). According to the authors, a model representing how LT CD $4+$ cells orchestrate immune responses depending on environmental signals and immunological challenges was identified as the most antifragile system, probably because it has the most variable environment. If we consider the interaction of two complex and variable systems-herbal medicines and diseases-it is likely to obtain antifragile responses for the desired pharmacological effects.

The synergism between the constituents of several plant extracts has been fully demonstrated (Caesar and Cech 2019). It is now time to move further and start investigating the antifragility properties of herbal medicines and their unconventional pharmacodynamic effects elicited in system therapeutics. System therapeutics differ from current drugs 
Fig. 1 Modulation of molecular networks of humans elicited by a single drug (A) and by an herbal preparation $(\mathbf{B})$. A single drug can induce biological response by affecting a certain number of modules (A), whereas a mixture of compounds found in an herbal preparation potentially interacts with a higher number and structurally diverse modules, in addition to create new interaction between the modules (B). Therefore, we hypothesize that the pharmacological effect of herbal medicines surpasses the canonical pharmacodynamics mechanisms, including synergistic effects, and the final activity can be affected by antifragile dynamics. C Taleb (2018) addressed antifragility as a mathematical property for local convex response, meaning a gain for the system, i.e., restoration of eubiosis as a response to a stressor, whereas fragility is the concave response, which induces harm to the system or dysbiosis
(A)

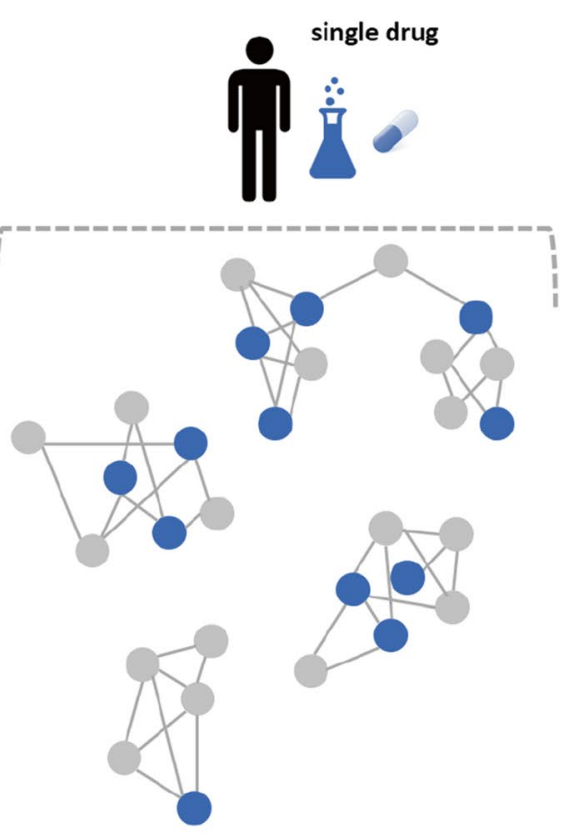

(B)
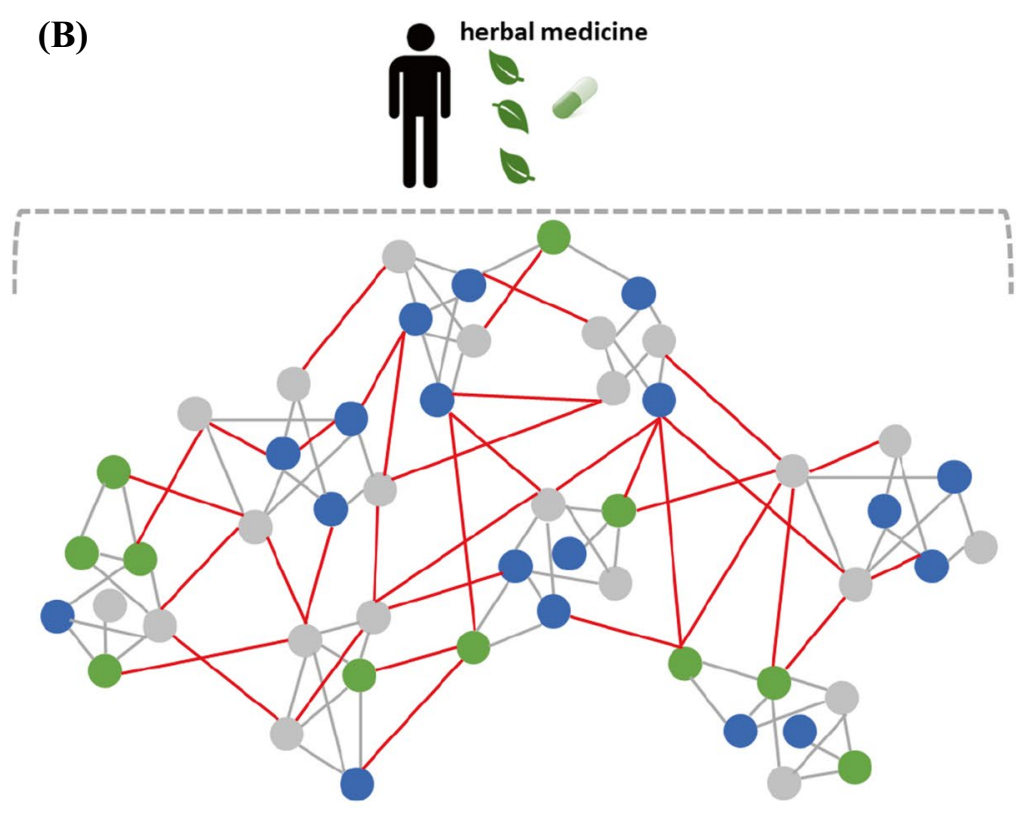

(C)

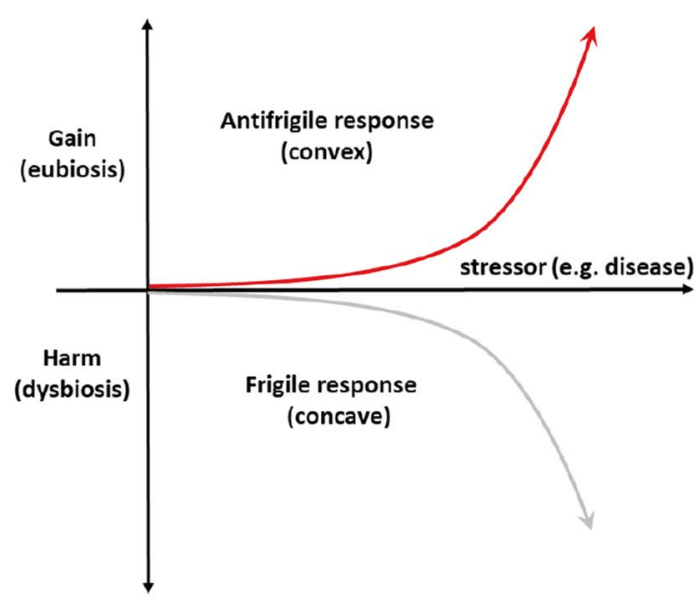


because they target biological networks rather than single transduction pathways and affect disease processes rather than physiological processes (Danhof et al. 2018). This change of paradigm demands the use of new tools to measure the biological response, and antifragility seems to be tailed to this purpose. The local industries should embrace the opportunity to develop innovative products from the Brazilian biodiversity, highlighting their antifragility properties, a finding that may present unique competitiveness in the international market.

\section{Adopting Principles of Circular Economy}

In general terms, circular economy is defined as a transition from a linear model (take, make, use, dispose) to a circular model (restorative and regenerative) (Fig. 2) (EMF, 2015). According to the United Nations, the circular economy can be seen as a means of progressing towards sustainable development through achieving the Sustainable Development Goals (SDG) (United Nations 2018). The circular economy is linked with the bioeconomy concept, defined as the use of renewable biological resources from land and sea, like crops, forests, fish, animals, and microorganisms, to produce food, materials, and energy. This concept is the focus of a key element of the circular economy model, which includes optimizing resource yields in biological cycles, as well as technical cycles (WHO 2018). It is currently believed that the dominant linear economy will be gradually replaced by the circular economy concepts and business models. The transition to this new model can result in significant net health benefits that will contribute to the attainment of the SDGs. Some researchers advocate that WHO and the health and environment sectors should promote a health-friendly transition to a circular economy and support countries to define their strategies and translate them into action plans (WHO 2018).

A 2020 survey carried out by the European Federation of Pharmaceutical Industries and Associations (EPFIA) indicates that the circular economy is being prioritized by the industry. Supply chain initiatives like reducing $\mathrm{CO}_{2}$ emissions by raw material manufacturing, supplier engagement, and improvements in operations and designing out waste are the practices of the circular economy mostly adopted by the surveyed industries, while the processing of byproducts has been also described (EFPIA 2020).

A recent publication reviews several plant wastes and byproducts and their potential use in various fields within the concept of the circular economy, especially for their exploitation in human healthcare and food (Chiocchio et al. 2021). According to the authors, the number of scientific publications on the theme has increased markedly in the last 3 years, reflecting the expanding global interest in the circular economy and requalification of neglected plant matrices. Polyphenols, terpenes, and alkaloids are representative examples of compounds found in plant wastes with potential for drug development. For instance, pomace-a byproduct of wine production-is recognized as a source of polyphenols like gallic, syringic, and vanillic acids; catechin; isoquercitrin; and epicatechin (Moldovan et al. 2019). Triterpenes like oleanolic, betulinic, and ursolic acids are other examples
Fig. 2 Representation of the linear economy model (A) and the circular economy model (B) (based on AkzoNobel, 2015)

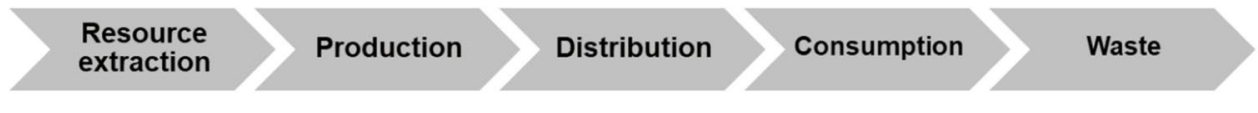

(A)

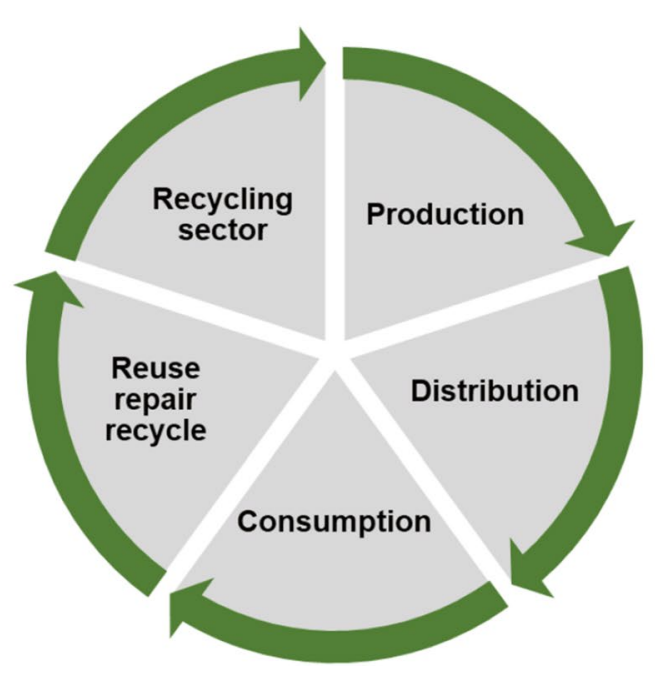

(B) 
of high-value products for medicinal purposes exploitation. Oleanolic acid is a constituent of olive trees (Olea europaea L., Oleaceae) wastes, produced at huge amounts, that can be extracted and contribute to improve the olive oil production chain (Cláudio et al. 2018).

There are probably several byproducts from Brazilian plants_-including medicinal and edible species — that might present potential of exploitation for medicinal purposes. A revision of these plants is beyond the goal of this article; however, two species will be herein highlighted in view of their proven pharmacological activities and relevance of their agricultural cultivation. Both species fit well in the principles of the circular economy, and their exploitation for medicinal purposes would satisfy the whole chain of production, also aligned with SDGs. The first species is a fruit tree, Hancornia speciosa Gomes, Apocynaceae, popularly known as "mangaba" or "mangabeira." The fruits are consumed in natura and used to produce ice creams, juices, and jams, among other products. The species is cultivated in Northeast Brazil and has special economical relevance to local communities. We have demonstrated the antihypertensive properties of $H$. speciosa leaves by in vitro, ex vivo, and in vivo assays (Serra et al. 2005; Ferreira et al. 2007a, 2007b; Silva et al. 2011, 2016; Endringer et al. 2014; Moreira et al. 2019), and these results led to a standardized extract enriched in cyclitols and flavonoids, which is intended to be developed as an herbal medicine to treat hypertension (Braga et al. 2009). The cyclitol L-(+)-bornesitol (7) is the main hypotensive constituent of the standardized extract (Pereira et al. 2012; Moreira et al. 2019), and it presents favorable pharmacokinetics in rats (Moreira et al. 2020). The leaves of "mangaba" are a renewable source for exploitation, containing high amounts of bornesitol, which was the first cyclitol described as a new class of angiotensin-converting enzyme (ACE) inhibitors (Endringer et al. 2014). There are no doubts on the potentialities of exploiting "mangaba" leaves for developing an antihypertensive herbal medicine or as a source of the bioactive constituent bornesitol.

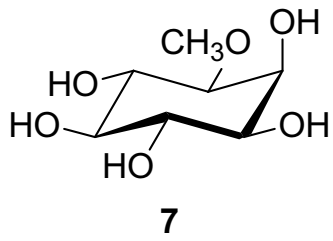

The second species is Caryocar brasiliense A.St.-Hil., Caryocaraceae, an arborous species popularly known as "pequizeiro." The tree is cultivated for the economic exploitation of the fruits, named pequi with an edible pulp, whereas the fruit peels are discharged. We established a standardized fraction from pequi peels enriched in tannins, including corilagin (8) and geraniin (9), and demonstrated its potential to manage type 2 diabetes by in vitro and in vivo models (Caldeira et al. 2020). This standardized fraction has a high potential to be developed as an antidiabetic herbal medicine. Besides, several biological and pharmacological activities have been reported for corilagin ( $\mathrm{Li}$ et al. 2018) and geraniin (Santhi et al. 2021), and their identification as constituents of a byproduct from pequi fruits may enable their exploitation for medicinal purposes. Interestingly, it has been recently demonstrated that corilagin prevents SARSCoV-2 infection (Yang et al. 2021) and is a potential inhibitor of SARS-CoV-2 variants (Binette et al. 2021), a finding that may enhance the interest on the antiviral properties of this tannin, and on the identification of new sources for its extraction.

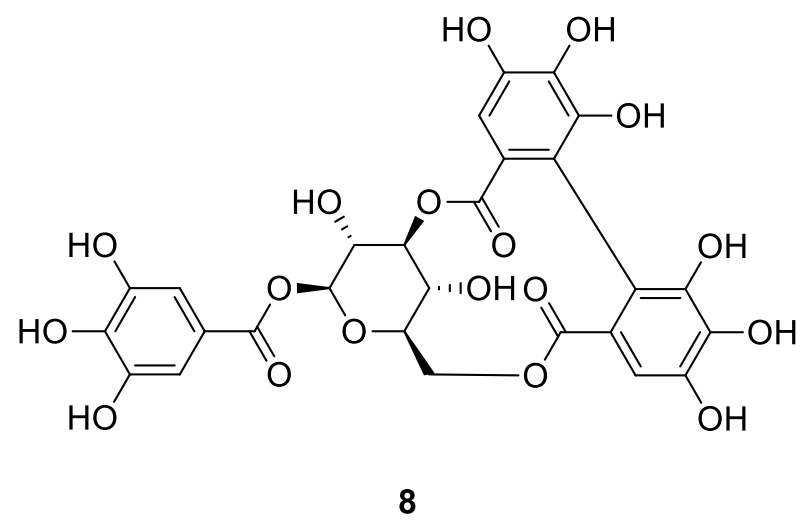

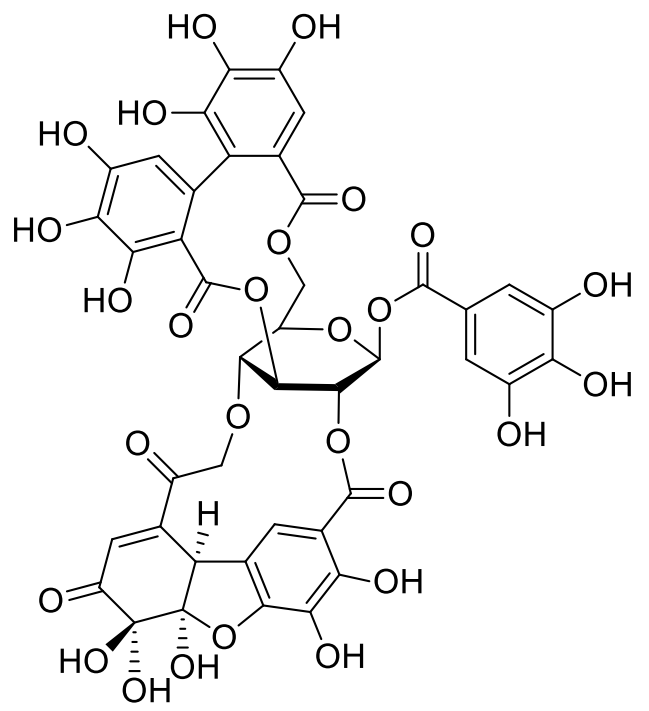




\section{Perspectives and Future Directions}

Brazil has a huge potential to receive investments for biodiversity exploitation aiming at drug development. To accomplish that, it is mandatory to establish a policy that favors innovation, encouraging investments, and to expand the scientific exchanges between national and international researchers, in addition to adopt a defined and stable regulatory framework that adequately protects intellectual property. The "Biodiversity Law" (No. 13123) established in 2015 is the regulatory mark for the exploitation of the Brazilian biodiversity. Although some aspects of the law may hamper the scientific research in public institutions, it establishes the required security for partners to develop products, assuring the benefit sharing for conservation and sustainable use of biodiversity.

According to the Brazilian Pharmaceutical Industry Union, the development of the national pharmaceutical sector should be based on the following equation: stimulating local production, stimulating innovation, establishment of a favorable environment for inhouse clinical research, and the adoption of public policies to allow access to medicines (Sindusfarma 2021). Innovation seems to be a key feature for the successful development of herbal medicines, and two new approaches can be explored for launching new competitive products. The first is based on the exploitation of the antifragility properties of herbal products in alignment with the concepts of system biology. Through this approach, it can be demonstrated that the pharmacological effects of herbal medicines surpass the canonical pharmacodynamics mechanisms, synergism included. The second approach proposes implementing the circular economy principles to produce herbal products, including the use of byproducts for the development of new therapeutical agents. Herbal medicines are suited to the circular economy principles since a whole production chain can be affected and benefitted from their manufacture.

\section{Conclusions}

The use of plants for medicinal purposes is a trace of the Brazilian cultural identity since its founding as a nation. Despite the richness of its flora, the number of medicines currently available in the market derived from the Brazilian biodiversity is limited, either as single drugs or herbal medicines. The use of medicinal plants experienced a continuous decline along the centuries, and the national pharmaceutical industry was negatively impacted by the installation of transnational companies in the 1950s. The national pharmaceutical companies were propelled by the manufacture of generic drugs, which now account for $57.62 \%$ of the market in revenues (Sindusfarma 2021). However, the successful economic growth has not been translated into radical or incremental innovation in products, and the development of new biodiversity-based products remains scarce. The absence of solid and long-term public policies to improve the pharmaceutical sector seems to be a fundamental aspect to explain the low success in this enterprise. Previous government initiatives undertaken to foster herbal medicines development did not result in new products, a fact that may be explained by the limited amounts of resources dispended, the absence of a central coordination, and the sporadic character to the development programs.

To conclude, it should be highlighted that the country presently possesses the required fundamental basis to move a step ahead in the development of biodiversity-based products. We cannot waste the opportunity to assume a leadership position on the development of herbal medicines following the new paradigms of the twenty-first century, especially the circular economy principles. It is now time to move on from the prologue and arise from our splendid cradle to start building the first chapter of a golden age in research and development of biodiversity-based products in Brazil.

Acknowledgements Conselho Nacional de Desenvolvimento Científico e Tecnológico $(\mathrm{CNPq} / \mathrm{Brazil})$ is acknowledged for a research fellowship (grant number 310755/2017-4).

\section{Declarations}

Conflict of Interest The author declares no competing interests.

\section{References}

AkzoNobel (2015) The circular economy. http://report.akzonobel. com/2015/ar/case-studies/the-circular-economy.html. Accessed 21 July 2021

Anvisa (2010) Farmacopoeia Brasileira, Vol 2, Monografias 5a edição 2010. Agência Nacional de Vigilância Sanitária, Ministério da Saúde, Brasília, DF. https://www.gov.br/anvisa/pt-br/assuntos/ farmacopeia/farmacopeia-brasileira/arquivos/8008json-file-1. Accessed 12 July 2021

Anvisa (2019) Farmacopoeia Brasileira, Vol 2, Monografias 6a edição 2019. Agência Nacional de Vigilância Sanitária, Ministério da Saúde, Brasília, DF. https://www.gov.br/anvisa/pt-br/assuntos/ farmacopeia/farmacopeia-brasileira/arquivos/7989json-file-1. Accessed 15 July 2021

Barbosa MO, Lemos ICS, Kerntopf MR, Fernandes GO (2016) A prática da medicina tradicional no Brasil: um resgate histórico dos tempos coloniais. RIES 5:65-77. https://doi.org/10.33362/ ries.v5i1.832

Bermudez JAZ, Epsztejn R, Oliveira MA, Hasenclever L (2000) $\mathrm{O}$ acordo TRIPS da OMC e a proteção patentária no Brasil: 
mudanças recentes e implicações para a produção local e o acesso aos medicamentos. Fiocruz/ENSP, Rio de Janeiro. http://www6. ensp.fiocruz.br/repositorio/resource/358620. Accessed 15 July 2021

Binette V, Côté S, Haddad M, Nguyen PT, Bélanger S, Bourgault S, Ramassamy C, Gaudreault R, Mousseau N (2021) Corilagin and 1,3,6-tri- $O$-galloy- $\beta$-D-glucose: potential inhibitors of SARSCoV-2 variants. Phys Chem Chem Phys 23:14873-14888. https:// doi.org/10.1039/d1cp01790j

Bizzarri M, Giuliani A, Monti N, Verna R, Pensotti A, Cucina A (2020) Rediscovery of natural compounds acting via multitarget recognition and noncanonical pharmacodynamical actions. Drug Discov Today 25:920-927. https://doi.org/10.1016/j.drudis.2020.02.010

Boing AC, Ribeiro Santiago PH, Tesser CD, Furlan IL, Bertoldi AD, Boing AF (2019) Prevalence and associated factors with integrative and complementary practices use in Brazil. Complement Ther Clin Pract 37:1-5. https://doi.org/10.1016/j.ctcp.2019.07.009

Braga FC, Endringer DC, Silva GC, Cortes SF (2009) Extrato e fração padronizados de folhas de Hancornia speciosa e sua composição farmacêutica. INPI patent PI0802004-3 A2, Brazil

Brandão MGL, Cosenza GP, Pereira FL, Vasconcelos AS, Fagg CW (2013) Changes in the trade in native medicinal plants in Brazilian public markets. Environ Monit Assess 185:7013-7023. https://doi. org/10.1007/s10661-013-3081-y

Brandão MGL, Gomes CG, Nascimento AM (2006) Plantas nativas da medicina tradicional brasileira: uso atual e necessidade de proteção. Rev Fitos 2:24-29

Buenz EJ, Verpoorte R, Bauer BA (2018) The ethnopharmacologic contribution to bioprospecting natural products. Annu Rev Pharmacol Toxicol 58:509-530. https://doi.org/10.1146/annurevpharmtox-010617-052703

Caesar LK, Cech NB (2019) Synergy and antagonism in natural product extracts: when $1+1$ does not equal 2. Nat Prod Rep 36:869888. https://doi.org/10.1039/c9np00011a

Caldeira ASP, Mbiakop UC, Pádua RM, van de Venter M, Matsabisa MG, Campana PRV, Cortes SF, Braga FC (2020) Bioguided chemical characterization of pequi (Caryocar brasiliense) fruit peels towards an anti-diabetic activity. Food Chem 345:128734. https://doi.org/10.1016/j.foodchem.2020.128734

Calixto JB (2005) Twenty-five years of research on medicinal plants in Latin America: a personal view. J Ethnopharmacol 100:131-134. https://doi.org/10.1016/j.jep.2005.06.004

Calixto JB (2019) The role of natural products in modern drug discovery. An Acad Bras Ciênc 91:e20190105. https://doi.org/10.1590/ 0001-3765201920190105

Carvalho ACB, Lana TN, Perfeito JPS, Silveira D (2018) The Brazilian market of herbal medicinal products and the impacts of the new legislation on traditional medicines. J Ethnopharmacol 212:29-35. https://doi.org/10.1016/j.jep.2017.09.040

Centro de Gestão e Estudos Estratégicos (2017) Competências para inovar na indústria farmacêutica brasileira. CGEE, Brasília. https://www.cgee.org.br/documents/10182/734063/Ind_farma ceutica.pdf. Accessed 15 July 2021

Chiocchio I, Mandrone M, Tomasi P, Marincich L, Poli F (2021) Plant secondary metabolites: an opportunity for circular economy. Molecules 26:495. https://doi.org/10.3390/molecules26020495

Cláudio AFM, Cognigni A, de Faria EL, Silvestre AJ, Zirbs R, Freire MG, Bica K (2018) Valorization of olive tree leaves: extraction of oleanolic acid using aqueous solutions of surface-active ionic liquids. Sep Purif Technol 204:30-37. https://doi.org/10.1016/j. seppur.2018.04.042

Crouzeilles R, Feltran-Barbieri R, Ferreira MS, Strassburg BBN (2017) Hard times for the Brazilian environment. Nat Ecol Evol 1:1213. https://doi.org/10.1038/s41559-017-0303-7

Danhof M, Klein K, Stolk P, Aitken M, Leufkens H (2018) The future of drug development: the paradigm shift towards systems therapeutics. Drug Discov Today 23:1990-1995. https://doi.org/ 10.1016/j.drudis.2018.09.002

Dutra RC, Campos MM, Santos AR, Calixto JB (2016) Medicinal plants in Brazil: pharmacological studies, drug discovery, challenges and perspectives. Pharmacol Res 112:4-29. https://doi. org/10.1016/j.phrs.2016.01.021

Edler FC (2013) Plantas nativas do Brasil nas farmacopeias portuguesas e europeias. Séculos XVII-XVIII. In: Kury LB (ed) Usos e circulação de plantas no Brasil: Séculos XVI-XIX. Andrea Jakobsson Estúdio Editorial, Rio de Janeiro, pp 94-137

EFPIA (2020) EFPIA white paper on circular economy. European Federation of Pharmaceutical Industries and Associations. https://efpia.eu/media/554663/circular-economy.pdf. Accessed 10 July 2021

EMF (2015) Towards a circular economy: business rationale for an accelerated transition. Ellen MacArthur Foundation. https:// www.ellenmacarthurfoundation.org/assets/downloads/TCE_ Ellen-MacArthur-Foundation-9-Dec-2015.pdf. Accessed 10 July 2021

Endringer D, Oliveira O, Braga F (2014) In vitro and in silico inhibition of angiotensin-converting enzyme by carbohydrates and cyclitols. Chem Pap 68:37-45. https://doi.org/10.2478/s11696-013-0407-8

Fatovich DM (2021) Research, kindness and the antifragility of emergency medicine. Emerg Med Australas 33:385-387. https://doi. org/10.1111/1742-6723.13730

Ferreira HC, Serra CP, Lemos VS, Braga FC, Cortes SF (2007a) Nitric oxide-dependent vasodilatation by ethanolic extract of Hancornia speciosa via phosphatidyl-inositol 3-kinase. J Ethnopharmacol 109:161-164. https://doi.org/10.1016/j.jep.2006.06.009

Ferreira HC, Serra CP, Endringer DC, Lemos VS, Braga FC, Cortes SF (2007b) Endothelium-dependent vasodilation induced by Hancornia speciosa in rat superior mesenteric artery. Phytomedicine 14:473-478. https://doi.org/10.1016/j.phymed.2006.11.008

Fiorini RA, De Giacomo P, L'Abate L (2015) Towards resilient telehealth support for clinical psychiatry and psychology: a strategic review. Stud Health Technol Inform 213:275-278

Flora do Brasil (2020) Jardim Botânico do Rio de Janeiro. http://flora dobrasil.jbrj.gov.br/. Accessed 21 July 2021

Françoso MS, Strachman E (2013) A indústria farmacêutica no Brasil e na Índia: um estudo comparativo. Rev Econom 39:91-112. https:// doi.org/10.5380/re.v39i1.29747

Gadelha C, Maldonado J (2008) O papel da inovação na indústria farmacêutica: uma janela de oportunidade no âmbito do complexo industrial da saúde. Buss P, Carvalheiro J, Casas C (org) Medicamentos no Brasil: inovação e acesso. Editora Fiocruz, Rio de Janeiro, pp 41-59

Gomes RP, Pimentel VP, Cardoso ML, Pieroni JP (2014) O novo cenário de concorrência na indústria farmacêutica brasileira. BNDES Setorial 39:97-134

Gong P, Cui N, Wu L, Liang Y, Hao K, Xu X, Tang W, Wang G, Hao $\mathrm{H}$ (2012) Chemicalome and metabolome matching approach to elucidating biological metabolic networks of complex mixtures. Anal Chem 84:2995-3002. https://doi.org/10.1021/ac3002353

Goodacre R (2019) The blind men and the elephant: challenges in the analysis of complex natural mixtures. Faraday Discuss 218:524 539. https://doi.org/10.1039/c9fd00074g

Gurgel C (2011) Doenças e curas: o Brasil nos primeiros séculos. Contexto, São Paulo

Jörg M, Madden KS (2021) The right tools for the job: the central role for next generation chemical probes and chemistry-based target deconvolution methods in phenotypic drug discovery. RSC Med Chem 12:646-665. https://doi.org/10.1039/d1md00022e

Kaempf JW, Schmidt NM, Rogers S, Novack C, Friant M, Wang L, Tipping N (2017) The quest for sustained multiple morbidity reduction in very low-birth-weight infants: the antifragility project. J Perinatol 37:740-746. https://doi.org/10.1038/jp.2017.7 
Khan SR, Al Rijjal D, Piro A, Wheeler MB (2021) Integration of AI and traditional medicine in drug discovery. Drug Discov Today 26:982-992. https://doi.org/10.1016/j.drudis.2021.01.008

Kim H, Muñoz S, Osuna P, Gershenson C (2020) Antifragility predicts the robustness and evolvability of biological networks through multi-class classification with a convolutional neural network. Entropy 22:986. https://doi.org/10.3390/e22090986

Kinch MS, Kinch GA, Griesenauer RH (2019) Lost medicines: a longer view of the pharmaceutical industry with the potential to reinvigorate discovery. Drug Discov Today 24:382-389. https://doi.org/ 10.1016/j.drudis.2018.09.006

Larson G, Loayza N, Woolcock M (2016) The middle-income trap: myth or reality? Research and Policy Briefs 104230, The World Bank. https://ideas.repec.org/p/wbk/wbkrpb/104230.html. Accessed 19 July 2021

Li X, Deng Y, Zheng Z, Huang W, Chen L, Tong Q, Ming Y (2018) Corilagin, a promising medicinal herbal agent. Biomed Pharmacother 99:43-50. https://doi.org/10.1016/j.biopha.2018.01.030

Looareesuwan S, Chulay JD, Canfield CJ, Hutchinson DB (1999) Malarone (atovaquone and proguanil hydrochloride): a review of its clinical development for treatment of malaria. Malarone Clinical Trials Study Group. Am J Trop Med Hyg 60:533-541. https://doi. org/10.4269/ajtmh.1999.60.533

Mello JF (1980) Plants in traditional medicine in Brazil. J Ethnopharmacol 2:49-55. https://doi.org/10.1016/0378-8741(80)90030-6

Ministério da Saúde (2006) A fitoterapia no SUS e o Programa de Pesquisa de Plantas Medicinais da Central de Medicamentos. Secretaria de Ciência, Tecnologia e Insumos Estratégicos. Departamento de Assistência Farmacêutica. Ministério da Saúde, Brasília, 146 p. (Série B. Textos Básicos de Saúde)

Ministério da Saúde (2009). Portaria Interministerial no 2.960. Aprova o Programa Nacional de Plantas Medicinais e Fitoterápicos e cria o Comitê Nacional de Plantas Medicinais e Fitoterápicos. Programa Nacional de Plantas Medicinais e Fitoterápicos, Secretaria de Ciência, Tecnologia e Insumos Estratégicos, Departamento de Assistência Farmacêutica e Insumos Estratégicos, 136 p. (Série C. Projetos, Programas e Relatórios)

Moldovan ML, Iurian S, Puscas C, Silaghi-Dumitrescu R, Hanganu D, Bogdan C, Vlase L, Oniga I, Benedec D (2019) A design of experiments strategy to enhance the recovery of polyphenolic compounds from Vitis vinifera by-products through heat reflux extraction. Biomolecules 9:529. https://doi.org/10.3390/biom9 100529

Moreira LN, Silva GC, Câmara DV, Pádua RM, Lemos VS, Braga FC, Cortes SF (2019) The cyclitol L-(+)-bornesitol as an active marker for the cardiovascular activity of the Brazilian medicinal plant Hancornia speciosa. Biol Pharm Bull 42:2076-2082. https://doi.org/10.1248/bpb.b19-00601

Moreira LN, Feltrin C, Gonçalves JE, de Castro WV, Simões CMO, de Pádua RM, Cortes SF, Braga FC (2020) Determination of L-(+)bornesitol, the hypotensive constituent of Hancornia speciosa, in rat plasma by LC-MS/MS and its application on a pharmacokinetic study. Biomed Pharmacother 132:110900. https://doi.org/ 10.1016/j.biopha.2020.110900

Newman DJ (2017) The influence of Brazilian biodiversity on searching for human use pharmaceuticals. J Braz Chem Soc 28:402-414. https://doi.org/10.21577/0103-5053.20160225

Oliveira N (2005) Inovação e produção na química fina. Quim Nova 28:S79-S85. https://doi.org/10.1590/S0100-40422005000700015

Paranhos J, Mercadante E, Hasenclever L (2019) Os esforços inovativos das grandes empresas farmacêuticas no Brasil: o que mudou na última década? ENEI - Encontro Nacional de Economia Industrial e Inovação, 4, Campinas, São Paulo. https://bit.ly/2ZnRbVl. Accessed 2 July 2021

Pereira AB, Veríssimo TM, Oliveira MA, Araujo IA, Alves RJ, Braga FC (2012) Development and validation of an HPLC-DAD method for quantification of bornesitol in extracts from Hancornia speciosa leaves after derivatization with $p$-toluenesulfonyl chloride. J Chromatogr B Analyt Technol Biomed Life Sci 887-888:133137. https://doi.org/10.1016/j.jchromb.2012.01.009

Pimentel VP, Vieira VAM, Mitidieri TL, Oliveira FFS, Pieroni JP (2015) Biodiversidade brasileira como fonte da inovação farmacêutica: uma nova esperança? Rev BNDES 43:41-89

Pineda OK, Kim H, Gershenson C (2019) A novel antifragility measure based on satisfaction and its application to random and biological Boolean networks. Complexity 2019:3728621. https://doi.org/10. $1155 / 2019 / 3728621$

Piso W, Marggraf GL (1648) Historia naturalis Brasiliae. https://www. obrasraras.fiocruz.br/media.details.php?mediaID $=35$. Accessed 30 June 2021

Quental C, Abreu JA, Bomtempo JV, Gadelha CAG (2008) Medicamentos genéricos no Brasil: impactos das políticas públicas sobre a indústria nacional. Ciênc Saúde Col 13:619-628. https://doi.org/ 10.1590/S1413-81232008000700011

Ribeiro LHR (2019) Análise dos programas de plantas medicinais e fitoterápicos no Sistema Único de Saúde (SUS) sob a perspectiva territorial. Ciênc Saúde Colet 24:1733-1742. https://doi.org/10. 1590/1413-81232018245.15842017

Rodrigues ML, Morel CM (2016) The Brazilian dilemma: increased scientific production and high publication costs during a global health crisis and major economic downturn. mBio 7:e00907-16. https://doi.org/10.1128/mBio.00907-16

Saethre EJ (2007) Conflicting traditions, concurrent treatment: medical pluralismo in remote aboriginal Australia. Oceania 77:95-110

Sant'Ana PJP, Assad ALD (2004) Programa de pesquisa em produtos naturais: a experiência da CEME. Quim Nova 27:508-512. https:// doi.org/10.1590/S0100-40422004000300025

Santhi VP, Masilamani P, Sriramavaratharajan V, Murugan R, Gurav SS, Sarasu VP, Parthiban S, Ayyanar M (2021) Therapeutic potential of phytoconstituents of edible fruits in combating emerging viral infections. J Food Biochem 8:e13851. https://doi.org/10. $1111 /$ jfbc. 13851

Serra CP, Côrtes SF, Lombardi JA, Braga de Oliveira A, Braga FC (2005) Validation of a colorimetric assay for the in vitro screening of inhibitors of angiotensin-converting enzyme (ACE) from plant extracts. Phytomedicine 12:424-432. https://doi.org/10.1016/j. phymed.2004.07.002

Silva GC, Braga FC, Lima MP, Pesquero JL, Lemos VS, Cortes SF (2011) Hancornia speciosa Gomes induces hypotensive effect through inhibition of ACE and increase on NO. J Ethnopharmacol 137:709-713. https://doi.org/10.1016/j.jep.2011.06.031

Silva GC, Braga FC, Lemos VS, Cortes SF (2016) Potent antihypertensive effect of Hancornia speciosa leaves extract. Phytomedicine 23:214-219. https://doi.org/10.1016/j.phymed.2015.12.010

Silva Junior CHL, Pessôa ACM, Carvalho NS, Reis JBC, Anderson LO, Aragão LEOC (2020) The Brazilian Amazon deforestation rate in 2021 is the greatest of the decade. Nat Ecol Evol 5:144 145. https://doi.org/10.1038/s41559-020-01368-x

Sindusfarma (2021) Perfil da indústria farmacêutica e aspectos relevantes do setor. https://sindusfarma.org.br/uploads/files/229dgerson-almeida/Publicacoes_PPTs/Perfil_da_IF_2021_SINDU SFARMA_po.pdf. Accessed 25 July 2021

Skirycz A, Kierszniowska S, Méret M, Willmitzer L, Tzotzos G (2016) Medicinal bioprospecting of the Amazon rainforest: a modern Eldorado? Trends Biotechnol 34:781-790. https://doi.org/10. 1016/j.tibtech.2016.03.006

Souza ENF, Hawkins JA (2020) Ewé: a web-based ethnobotanical database for storing and analyzing data. Database 2020:bazz44. https://doi.org/10.1093/database/baz144

Tabajara de Oliveira Martins D, Rodrigues E, Casu L, Benítez G, Leonti M (2019) The historical development of pharmacopoeias and the inclusion of exotic herbal drugs with a focus on Europe 
and Brazil. J Ethnopharmacol 240:111891. https://doi.org/10. 1016/j.jep.2019.111891

Taleb NN (2012) Antifragile: things that gain from disorder. Random House Publishing Group, New York

Taleb NN (2018) (Anti)fragility and convex responses in medicine. In: Morales A, Gershenson C, Braha D, Minai A, Bar-Yam Y (eds) Unifying themes in complex systems IX. ICCS 2018. Springer Proceedings in Complexity. Springer, Cham. https://doi.org/10. 1007/978-3-319-96661-8_32

Teixeira LA, Edler FC (2012) História e cultura da medicina no Brasil. Aori Produções Culturais, São Paulo

Thomford NE, Senthebane DA, Rowe A, Munro D, Seele P, Maroyi A, Dzobo K (2018) Natural products for drug discovery in the 21st century: innovations for novel drug discovery. Int J Mol Sci 19:1578. https://doi.org/10.3390/ijms19061578

United Nations (2018) Sustainable Development Goals. http://www. un.org/sustainabledevelopment/sustainable-development-goals. Accessed 13 July 2021

Valli M, Bolzani VS (2019) Natural products: perspectives and challenges for use of Brazilian plant species in the bioeconomy. An Acad Bras Cienc 91:e20190208. https://doi.org/10.1590/00013765201920190208

Vieira FS, Santos MAB (2020) O setor farmacêutico no Brasil sob as lentes da conta-satélite de saúde Instituto de Pesquisa Econômica Aplicada, Brasília. https://doi.org/10.38116/td2615
WHO (2018) Circular economy and health: opportunities and risks. Copenhagen, World Health Organization. https://www.euro.who. int/_data/assets/pdf_file/0004/374917/Circular-Economy_EN_ WHO_web_august-2018.pdf. Accessed 13 July 2021

Wolfender JL, Litaudon M, Touboul D, Queiroz EF (2019) Innovative omics-based approaches for prioritisation and targeted isolation of natural products - new strategies for drug discovery. Nat Prod Rep 36:855-868. https://doi.org/10.1039/c9np00004f

Wouters OJ, McKee M, Luyten J (2020) Estimated research and development investment needed to bring a new medicine to market, 2009-2018. JAMA 323:844-853. https://doi.org/10.1001/jama. 2020.1166

Yang LJ, Chen RH, Hamdoun S, Coghi P, Ng JPL, Zhang DW, Guo X, Xia C, Law BYK, Wong VKW (2021) Corilagin prevents SARSCoV-2 infection by targeting RBD-ACE2 binding. Phytomedicine 87:153591. https://doi.org/10.1016/j.phymed.2021.153591

Zank S, Hanazaki N (2017) The coexistence of traditional medicine and biomedicine: a study with local health experts in two Brazilian regions. PLoS ONE 12:e174731. https://doi.org/10.1371/journ al.pone. 0174731

Zhang L, Song J, Kong L, Yuan T, Li W, Zhang W, Hou B, Lu Y, Du $G$ (2020) The strategies and techniques of drug discovery from natural products. Pharmacol Ther 216:107686. https://doi.org/10. 1016/j.pharmthera.2020.107686 